\title{
He-Ar isotope geochemistry of the Yaoling-Meiziwo tungsten deposit, North Guangdong Province: Constraints on Yanshanian crust- mantle interaction and metallogenesis in SE China
}

\author{
ZHAI Wei ${ }^{1,2^{*}}$, SUN XiaoMing ${ }^{1,2,3}$, WU YunShan ${ }^{3}$, SUN YanYan ${ }^{4}$, HUA RenMin $^{5} \&$ \\ YE XianRen ${ }^{6}$ \\ ${ }^{1}$ Guangdong Provincial Key Laboratory of Marine Resources and Coastal Engineering, Guangzhou 510006, China; \\ ${ }^{2}$ School of Marine Sciences, Sun Yat-sen University, Guangzhou 510275, China; \\ ${ }^{3}$ Department of Earth Sciences, Sun Yat-sen University, Guangzhou 510275, China; \\ ${ }^{4}$ Geological Survey Institute of Guangdong Nonferrous Metals Geological Survey Bureau, Guangzhou 510080, China; \\ ${ }^{5}$ State Key Laboratory of Mineral Deposit Research, Nanjing University, Nanjing 210093, China; \\ ${ }^{6}$ Institute of Geology and Geophysics, Chinese Academy of Sciences, Lanzhou 730000, China
}

Received September 26, 2011; accepted December 19, 2011; published online January 31, 2012

Isotopic abundances and ratios of $\mathrm{He}$ and $\mathrm{Ar}$ found in inclusion fluids in pyrites formed in the Yaoling-Meiziwo tungsten mineralization epoch show that the concentration of ${ }^{4} \mathrm{He}$ varies widely, from $1.54 \times 10^{-7} \mathrm{~cm}^{3} \mathrm{STP} / \mathrm{g}$ to $2609 \times 10^{-7} \mathrm{~cm}^{3} \mathrm{STP} / \mathrm{g}$. ${ }^{3} \mathrm{He}$ is $0.759 \times 10^{-12} \mathrm{~cm}^{3} \mathrm{STP} / \mathrm{g}-3.463 \times 10^{-12} \mathrm{~cm}^{3} \mathrm{STP} / \mathrm{g} .{ }^{3} \mathrm{He} /{ }^{4} \mathrm{He}$ is $0.0043-4.362 \mathrm{Ra}$, varying from crustal to mantle values. The concentration of ${ }^{40} \mathrm{Ar}$ ranges from $0.624 \times 10^{-7} \mathrm{~cm}^{3} \mathrm{STP} / \mathrm{g}$ to $8.89 \times 10^{-7} \mathrm{~cm}^{3} \mathrm{STP} / \mathrm{g}$. The ${ }^{40} \mathrm{Ar} /{ }^{36} \mathrm{Ar}$ varies extensively, from 330 to 2952 , between atmospheric and crustal or mantle radiogenic values. Mantle-derived He is present in ore-forming fluids and the calculated average proportion of the mantle $\mathrm{He}$ is $22 \%$; the maximum is $67 \%$. Our research results show that mantle-derived fluids play a significant role in tungsten mineralization. The fractionation of $\mathrm{He}$ and $\mathrm{Ar}$ indicate that there was ${ }^{4} \mathrm{He}$-enriched air-saturated water (MSAW) in the ore-forming fluid. The ore-forming fluid was a mixture of mantle fluid, crustal magmatic fluid and MSAW. The occurrence of a mantle component in ore-forming fluid indicates the large-scale W and Sn mineralization, including Yaoling-Meiziwo, in southeastern China was the result of crust and mantle interaction. The underplating or intrusion of voluminous basaltic magma formed by partial melting of the upper mantle provided the necessary heat to cause partial melting of the crust and the generation of voluminous S-type granitic magmas. Crustal magmatic fluid and mantle fluid with high ${ }^{3} \mathrm{He} /{ }^{4} \mathrm{He}$ were released from magma crystallization and fractionation, mixed with the circulating modified air-saturated water, and filled the extensional tectonic fractures, leading to the formation of world-class W and Sn deposits in southeastern China.

Yaoling-Meiziwo tungsten deposit, He-Ar isotope, mantle fluid, crust-mantle interaction

Citation: Zhai W, Sun X M, Wu Y S, et al. He-Ar isotope geochemistry of the Yaoling-Meiziwo tungsten deposit, North Guangdong Province: Constraints on Yanshanian crust-mantle interaction and metallogenesis in SE China. Chin Sci Bull, 2012, 57: 1150-1159, doi: 10.1007/s11434-011-4952-7

With the development of noble gas isotopic geochemistry, a tracing system for noble gas isotopes has gradually been applied to studies of ore fluid origins [1-30]. As a result, in many metal deposits, mantle-derived He was discovered in ore fluids [1-5,7-10,12,15-23,25-29]. Mantle He in crustal rocks is intimately related to crust-mantle interaction, and

*Corresponding author (email: eeszw@mail.sysu.edu.cn) the formation and evolution of mantle magma. Mantle magma not only provides ore fluid for metallogenesis, but also provides heat for the hydrothermal circulation that results in mineralization. Southeastern China is an important area of tungsten and tin metallogenesis, both regionally and globally, with many large, supergiant deposits, such as the Xihuangshan, Dajishan, and Piaotang tungsten deposits in Jiangxi province, the Jubankeng and Yaoling-Meiziwo 
tungsten deposits in Guangdong Province, and the Furongtin deposit and Shizhuyuang tungsten-tin deposit in Hunan Province. Since the 1980 s, much research has been undertaken concerning the genesis of these deposits; generally, these deposits are considered to be intimately related to Yanshanian S-type granites, which are largely produced by crustal anatexis [31-36], and also predicate that ore fluid related to tungsten and tin metallogenesis was derived from the crust. However, if mantle fluid is part of the process of mineralization, the relationship between metallogenesis and crust-mantle interactions will be enigmatic. Our present research investigates $\mathrm{He}$ and $\mathrm{Ar}$ isotopes and the abundance of fluid inclusion in pyrites and the similar minerals at the Yaoling-Meiziwo deposit in north Guangdong Province. The investigation aims to determine the origin of ore fluids and constrain the relationship between Yanshanian crustmantle interaction processes, and large-scale tungsten and tin mineralization in southeastern China.

\section{Regional geological and metallogenic setting}

The Yaoling-Meiziwo tungsten deposit is located in Shaoguan city in northern Guangdong Province, China. The deposit occurs in the core of the Yaoling compound anticline, the axis of which strikes northwest, from western
Yaoling to the eastern Meiziwo tungsten deposit, forming the east-west trending Yaoling-Meiziwo tungsten metallogenic belt (Figure 1). The core of Yaoling compound anticline consists of a resource-rich group of tungsten deposits: three mid- to large-size tungsten deposits, Yaoling, Shirenzhang and Meiziwo, are distributed from west to east, and the smaller Shigushan and Hekoushan tungsten deposits also occur. Large tungsten deposits: Xihuashan, Dajishan, and Kuimeishan in Jiangxi Province, and Jubankeng in Guangdong, are found to the north, southeast, and south of the ore deposit belt.

The Cambrian to Ordovician strata that outcrop in the Yaoling compound anticline consist of epimetamorphic quartzite, slate, silicate and shale; Devonian and Carboniferous units are found in the southern and northern limb, and unconformably overlie the Cambrian to Ordovician. The lower part of the Devonian consists of quartz sandstone, psepholite; the middle part consists of limestone and argillaceous limestone interlayered with bioclastic limestone; the upper part consists of siltstone. The Carboniferous consists of limestone and argillaceous siltstone. The Cretaceous consists of subaerial clastic rocks and volcanic rocks, distributed in the Nanxiong Basin located in the north.

In the region, magmatic intrusive rocks are distributed widely. In the north of the Yaoling-Meiziwo tungsten metallogenic belt, the Yanshanian Jiufeng granite pluton

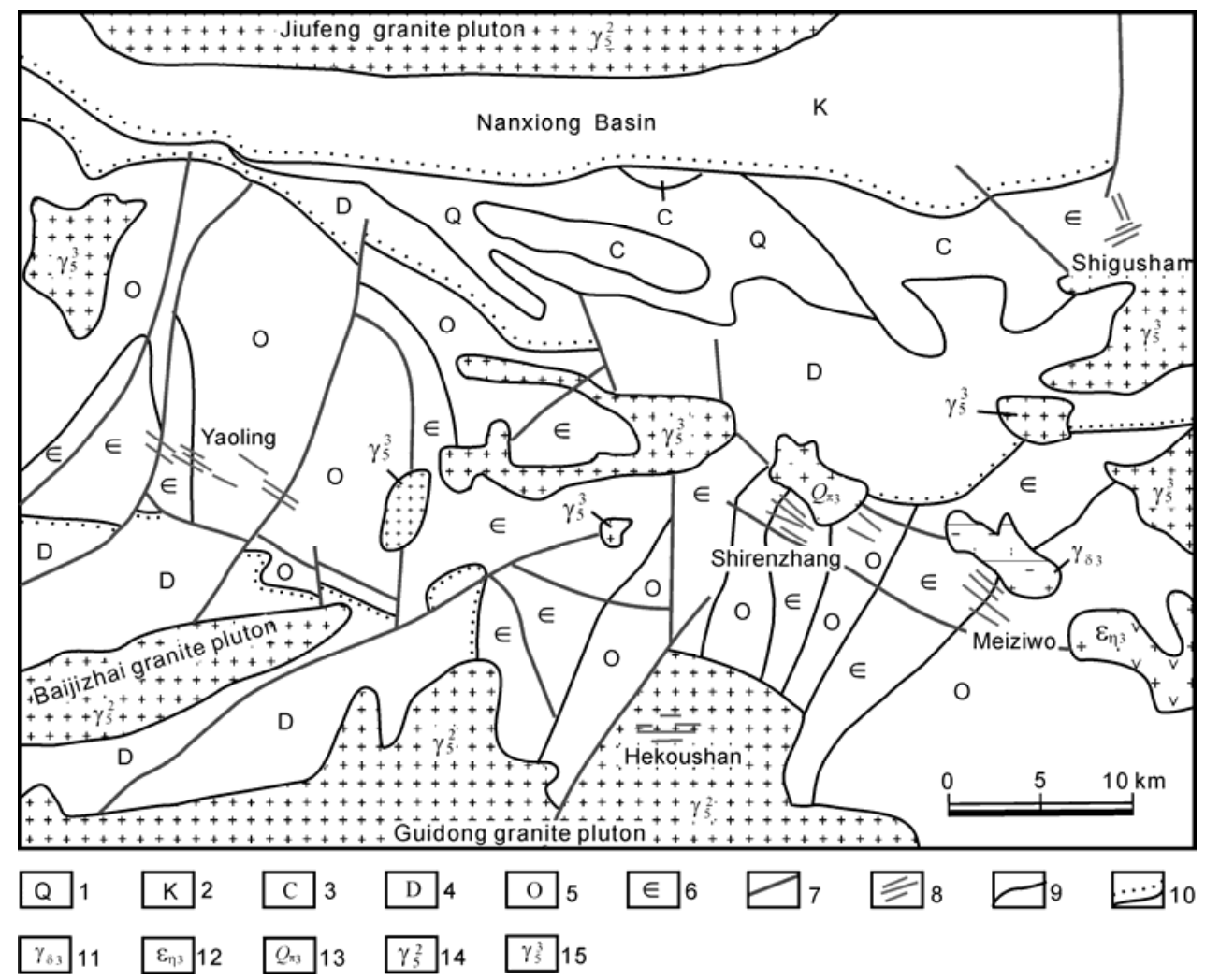

Figure 1 Geology map of the Yaoling-Meiziwo tungsten deposit. Modified after references [37,38]. 1, Quaternary; 2, Cretaceous; 3, Carboniferous; 4, Devonian; 5, Ordovician; 6, Cambrian; 7, fault; 8, wolframite quartz-vein; 9, geological boundary; 10, unconformable boundary; 11, granodiorite; 12, dacitic porphyry; 13 , quartz porphyry; 14 , granite; 15 , monzogranite. 
$\left(\gamma_{5}^{2}\right)$ outcrops in the Nanxiong Basin, the Yanshanian Guidong granite pluton with a large distributed area outcrops in the south, and the Yanshanian Baijizhai monzogranite $\left(\gamma_{5}^{2}\right)$ outcrops in the southern of Yaoling tungsten deposit. The Caledonian granodiorite $\left(\gamma_{\delta 3}\right)$, quartz porphyry $\left(Q_{\pi 3}\right)$, dacite-porphyry $\left(\varepsilon_{\eta 3}\right)$ and Yanshanian two-mica granite $\left(\gamma_{5}^{3}\right)$ occur periodically in the core of the Yaoling-Meiziwo compounded anticline.

\section{Geology of the ore deposits}

The outcrop strata associated with the Yaoling-Meiziwo ore deposits are Cambrian to Ordovician epimetamorphic terrestrial clastic rocks consisting of quartz sandstone, psepholite, siltstone, limestone and argillaceous limestone. The Yanshanian Baijizhai monzogranite $\left(\gamma_{5}^{2}\right)$ outcrops in the southern part of the Yaoling tungsten deposit, and a buried biotite monzogranite pluton occurs at a level of $450 \mathrm{~m}$ in the lower part of the ore; two monzogranitic pluton ages constrain the age to $158 \mathrm{Ma}$ [37]. Caledonian granodiorite plutons $\left(\gamma_{83}\right)$, with an age of $430 \mathrm{Ma}$ [38], occur in the northern part of the Meiziwo deposit and also occur below the $560 \mathrm{~m}$ level in the lower part of the ore. The buried Yanshanian biotite monzogranite pluton occurs below the $290 \mathrm{~m} \mathrm{level}$; the Caledonian dacite-porphyry $\left(\varepsilon_{\eta 3}\right)$ and quartz porphyry $\left(Q_{\pi 3}\right)$ outcrop in the form of small stocks in the northwestern and southeastern parts of the deposit respectively.

The ore bodies of Yaoling-Meiziwo are associated with wolframite-bearing quartz-veins that fill WNW-striking faults or cracks in Cambrian to Ordovician strata or in buried intrusive rocks. Ore vein assemblages are generally nearly perpendicular, dipping NE or SW at angles varying between $80^{\circ}$ and $90^{\circ}$. The maximum length of a single vein can extend to about $1300 \mathrm{~m}$, and the inclination depth can be more than $750 \mathrm{~m}$. The ore veins have the characteristics of the "five floor" metallogenic model summarized by Chi- nese scientists $[39,40]$ extending from the surface (at an elevation of 1020-1100 m) to the present mining level of $450 \mathrm{~m}$. Ore veins or mineralized quartz-veins vary steadily from (1) belts of micro veins which have thicknesses of less than $0.3 \mathrm{~cm}$, to (2) belts of sparse parallel fine veins with thicknesses $<10 \mathrm{~cm}$, to (3) belts of dense fine-thin veins with the thickness of a main vein $>10 \mathrm{~cm}$ and subordinate veins from 3 to $10 \mathrm{~cm}$, to (4) belts of thin veins with thicknesses on the order of $10 \mathrm{~cm}$, to (5) large veins with thicknesses of more than $1 \mathrm{~m}$.

Ore minerals consist mainly of wolframite, scheelite, cassiterite, chalcopyrite, pyrite, arsenopyrite, molybdenite, and bismuthinite. Gangue minerals consist mainly of quartz, tourmaline, fluorite, and muscovite. The main wall-rock alteration types at Yaoling-Meiziwo are greisenization, silicification, sericitization and fluoritization.

The ${ }^{40} \mathrm{Ar} /{ }^{39} \mathrm{Ar}$ metallogenic ages of the wolframite-bearing quartz-veins are $149 \mathrm{Ma}$ at Yaoling [37] and $156 \mathrm{Ma}$ at Meiziwo [38]. These ages are in accordance with largescale tungsten and tin metallogenesis in southeastern China from the middle Yanshanian period (ca. 150-160 Ma).

\section{Sample descriptions and analytical methods}

The sulfides pyrite, arsenopyrite, and molybdenite are scarce in the Yaoling-Meiziwo deposit. Where they occur, these minerals are euhedral to subhedral, coarse-grained (generally $1-5 \mathrm{~mm}$ in diameter, with a maximum of $10 \mathrm{~mm}$ ), and distributed homogeneously as grains in wolframite-bearing quartz-veins. Of the 14 samples used for noble gas isotopic analysis, 12 were pyrites, one was arsenopyrite, the other was wolframite. The samples from Yaoling deposit were recovered from underground ore vein Nos. 19, 21, and 63 at the $450 \mathrm{~m}$ level. The samples from Meiziwo were recovered from ore vein Nos. 12, 57, and 59 at the 640 and $760 \mathrm{~m}$ level. Sample descriptions are provided in Table 1.

Table 1 Location and brief descriptions of the samples used for this study

\begin{tabular}{lllll}
\hline \multicolumn{1}{c}{ Sample No. } & Location & Analysed mineral & Ore-vein & Mineral association \\
\hline 08YL-124-2 & $450 \mathrm{~m}$ level, Yaoling & pyrite & No. 26 & pyrite, chalcopyrite, wolframite, quartz \\
08YL-124-3 & $450 \mathrm{~m}$ level, Yaoling & pyrite & No. 26 & pyrite, chalcopyrite, wolframite, quartz, muscovite \\
08YL-124-4 & $450 \mathrm{~m}$ level, Yaoling & pyrite & No. 19 & pyrite, chalcopyrite, wolframite, quartz \\
08YL-124-5 & $450 \mathrm{~m}$ level, Yaoling & pyrite & No. 19 & pyrite, chalcopyrite, quartz \\
08YL-124-7 & $450 \mathrm{~m}$ level, Yaoling & wolframite & No. 26 & wolframite, quartz, muscovite \\
08YL-128-1 & $450 \mathrm{~m}$ level, Yaoling & pyrite & No. 21 & pyrite, chalcopyrite, bismuthinite, quartz \\
08YL-128-4 & $450 \mathrm{~m}$ level, Yaoling & pyrite & No. 21 & pyrite, chalcopyrite, quartz \\
08YL-450-63/2 & $450 \mathrm{~m}$ level, Yaoling & pyrite & No. 63 & pyrite, chalcopyrite, bismuthinite, quartz \\
08YL-450-63/4 & $450 \mathrm{~m}$ level, Yaoling & pyrite & No. 63 & pyrite, chalcopyrite, bismuthinite, molybdenite, quartz \\
08MZ-640-12/1 & $640 \mathrm{~m}$ level, Meiziwo & pyrite & No. 12 & pyrite, chalcopyrite, arsenopyrite, quartz, muscovite \\
08MZ-640-12/2 & $640 \mathrm{~m}$ level, Meiziwo & arsenopyrite & No. 12 & pyrite, chalcopyrite, arsenopyrite, quartz, muscovite \\
08MZ-640-59 & $640 \mathrm{~m}$ level, Meiziwo & pyrite & No. 59 & pyrite, galena, molybdenite, quartz \\
08MZ-760-57 & $760 \mathrm{~m}$ level, Meiziwo & pyrite & No. 57 & pyrite, chalcopyrite, wolframite, quartz \\
08MZ-760-57/1 & $760 \mathrm{~m}$ level, Meiziwo & pyrite & No. 57 & pyrite, arsenopyrite, wolframite, quartz, muscovite \\
\hline
\end{tabular}


The mineral samples were crushed into grains with a diameter of $0.5-2.0 \mathrm{~mm}$ and selected under binocular microscope to higher than $99 \%$ purity for the experiment. The contents and isotopic compositions of $\mathrm{He}$ and $\mathrm{Ar}$ were measured by a MM5400 mass spectrometer in the Laboratory of Gas Geochemistry (Lanzhou), Institute of Geology and Geophysics, Chinese Academy of Sciences. The analytical conditions were: It $4=800 \mu \mathrm{A}$, It $40=200 \mu \mathrm{A}$, with a high voltage of $9.000 \mathrm{kV}$. Samples (weight ca. $0.2 \mathrm{~g}$ ) for analysis were packed with aluminum foil and moved to a crucible for gas extraction under high vacuum conditions; a pressure lower than $1 \times 10^{-5} \mathrm{~Pa}$ was reached. The samples were heated at $130^{\circ} \mathrm{C}$ for at least $10 \mathrm{~h}$ to eliminate secondary fluid inclusions and trace gases occurring in cleavages or fractures in the crusts. The samples were fused in a crucible at a high temperature of up to $1500^{\circ} \mathrm{C}$, and the released gases were extracted by an ultra-high vacuum purifying system. The active gases $\mathrm{O}_{2}, \mathrm{~N}_{2}, \mathrm{CO}_{2}, \mathrm{SO}_{2}$, etc. were removed with a high-temperature titanium furnace. $\mathrm{H}_{2}$ was removed with a $\mathrm{ZrAl}$ suction pump. Remaining gases were absorbed and separated by active carbon at a liquid nitrogen temperature into $\mathrm{He}+\mathrm{Ne}$ and $\mathrm{Ar}+\mathrm{Ke}+\mathrm{Xe}$ for analysis. The accuracy of measured data was checked repeatedly by measuring the air standard (AIRLZ2003) collected from the top of Gaolan Mountain at Lanzhou City, China. Hot-blanks were run using the same procedure as the real samples. The hot-blank levels of $\mathrm{He}, \mathrm{Ne}, \mathrm{Ar}, \mathrm{Kr}$ and $\mathrm{Xe}$ at $1600^{\circ} \mathrm{C}\left(\mathrm{cm}^{3}\right.$ $\mathrm{STP})$ are ${ }^{4} \mathrm{He}=2.46 \times 10^{-10},{ }^{20} \mathrm{Ne}=4.08 \times 10^{-10},{ }^{40} \mathrm{Ar}$ $=1.39 \times 10^{-8},{ }^{84} \mathrm{Kr}=3.07 \times 10^{-12}$, and ${ }^{132} \mathrm{Xe}=1.26 \times 10^{-13}$. All noble gas isotopic compositions in the hot-blanks were approximately those of air. All results were calibrated to the hot-blanks; the details of the measuring process were described by Ye et al. $[41,42]$.

\section{Results and discussion}

The data measured from the 14 samples are provided in Table 2. ${ }^{4} \mathrm{He}$ varies within a large range, from $1.54 \times 10^{-7}$ $\mathrm{cm}^{3} \mathrm{STP} / \mathrm{g}$ to $2609 \times 10^{-7} \mathrm{~cm}^{3} \mathrm{STP} / \mathrm{g}$, whereas ${ }^{3} \mathrm{He}$ varies from $0.759 \times 10^{-12} \mathrm{~cm}^{3} \mathrm{STP} / \mathrm{g}$ to $3.463 \times 10^{-12} \mathrm{~cm}^{3} \mathrm{STP} / \mathrm{g}$. ${ }^{3} \mathrm{He} /{ }^{4} \mathrm{He}$ ratios range widely from 0.0043 to $4.362 \mathrm{Ra}$ (where $\mathrm{Ra}$ is the atmospheric ${ }^{3} \mathrm{He} /{ }^{4} \mathrm{He}$ ratio, $1.399 \times 10^{-6}$ ), between the mantle and crust. ${ }^{40} \mathrm{Ar}$ measurements are 0.624 $\times 10^{-7} \mathrm{~cm}^{3} \mathrm{STP} / \mathrm{g}$ to $8.89 \times 10^{-7} \mathrm{~cm}^{3} \mathrm{STP} / \mathrm{g} .{ }^{40} \mathrm{Ar} /{ }^{36} \mathrm{Ar}$ ratios also vary within a broad range, from 330 to 2952 , i.e. between atmospheric Ar and crustal or mantle radiogenic Ar.

\subsection{Noble gases in minerals and post entrapment modifications}

The noble gases $\mathrm{He}$ and Ar are mostly found in three settings: (1) trapped in fluid inclusions, (2) as lattice trapped ${ }^{4} \mathrm{He}$ and/or ${ }^{40} \mathrm{Ar}$ that is radioactively produced by $\mathrm{U}+\mathrm{Th}$ and/or $\mathrm{K}$ in the mineral lattice, and (3) trapped in annealed microfractures or absorbed on mineral surfaces. Rigorous procedures can minimize this latter type of atmospheric contamination, and in fact, much previous research has shown that noble gases in minerals (e.g. sulfides of hydrothermal deposit) mainly exist in fluid inclusions. However, the content and isotopic compositions of $\mathrm{He}$ and Ar may be modified after mineral crystallization, e.g. loss or addition by diffusion, accumulative addition through radiogenic decay, and gain through radiogenic reactions and/or the introduction of cosmogenic He.

Cosmogenic $\mathrm{He}$ is produced in the uppermost $1.5 \mathrm{~m}$ of the Earth's surface [43]. The research samples used here were mined from underground tunnels at different levels

Table 2 He-Ar abundance and isotopic compositions for Yaoling-Meiziwo tungsten deposit ${ }^{\text {a) }}$

\begin{tabular}{|c|c|c|c|c|c|c|c|c|c|c|c|c|}
\hline Sample No. & Mineral & $\begin{array}{l}\text { Weight } \\
(\mathrm{g})\end{array}$ & $\begin{array}{c}{ }^{4} \mathrm{He} \times 10^{-7} \\
\left(\mathrm{~cm}^{3} \mathrm{STP} / \mathrm{g}\right)\end{array}$ & $\begin{array}{c}{ }^{40} \mathrm{Ar} \times 10^{-7} \\
\left(\mathrm{~cm}^{3} \mathrm{STP} / \mathrm{g}\right)\end{array}$ & $\begin{array}{c}{ }^{3} \mathrm{He} /{ }^{4} \mathrm{He} \\
(\mathrm{Ra})\end{array}$ & ${ }^{38} \mathrm{Ar} /{ }^{36} \mathrm{Ar}$ & ${ }^{40} \mathrm{Ar} /{ }^{36} \mathrm{Ar}$ & $\begin{array}{c}\text { Mantle He } \\
(\%)\end{array}$ & $\begin{array}{l}{ }^{40} \mathrm{Ar} * \\
(\%)\end{array}$ & ${ }^{40} \mathrm{Ar} * /{ }^{4} \mathrm{He}$ & $\begin{array}{l}{ }^{3} \mathrm{He} \times 10^{-12} \\
\left(\mathrm{~cm}^{3} \mathrm{STP} / \mathrm{g}\right)\end{array}$ & $\mathrm{F}^{4} \mathrm{He}$ \\
\hline 08YL-124-2 & pyrite & 0.291 & $14.23 \pm 0.96$ & $2.72 \pm 0.18$ & $1.023 \pm 0.011$ & $0.159 \pm 0.016$ & $445.4 \pm 31.0$ & 15.61 & 33.66 & 0.0643 & 2.037 & 14122 \\
\hline 08YL-124-3 & pyrite & 0.290 & $2609 \pm 175$ & $3.47 \pm 0.24$ & $0.0043 \pm 0.0006$ & $0.1792 \pm 0.0095$ & $603.7 \pm 34.8$ & -0.09 & 51.05 & 0.0007 & 1.580 & 2750945 \\
\hline 08YL-124-4 & pyrite & 0.291 & $4.26 \pm 0.29$ & $0.624 \pm 0.043$ & $1.325 \pm 0.055$ & $0.135 \pm 0.026$ & $1368.5 \pm 190.1$ & 20.26 & 78.41 & 0.1148 & 0.790 & 56622 \\
\hline 08YL-124-5 & pyrite & 0.410 & $68.2 \pm 4.6$ & $7.99 \pm 0.54$ & $0.363 \pm 0.033$ & $0.1880 \pm 0.0069$ & $551.9 \pm 23.4$ & 5.44 & 46.46 & 0.0544 & 3.463 & 28551 \\
\hline 08YL-124-7 & wolframite & 0.292 & $418 \pm 28$ & $2.51 \pm 0.17$ & $0.0304 \pm 0.0013$ & $0.147 \pm 0.015$ & $717.1 \pm 37.6$ & 0.31 & 58.79 & 0.0035 & 1.778 & 1289 \\
\hline 08YL-128-4 & pyrite & 0.411 & $6.51 \pm 0.44$ & $4.20 \pm 0.29$ & $1.598 \pm 0.034$ & $0.170 \pm 0.016$ & $360.1 \pm 27.0$ & 24.47 & 17.94 & 0.1157 & 1.455 & 686 \\
\hline 08YL-450-63/2 & pyrite & 0.295 & $3.02 \pm 0.21$ & $8.89 \pm 0.61$ & $2.623 \pm 0.081$ & $0.181 \pm 0.016$ & $333.2 \pm 9.1$ & 40.26 & 11.31 & 0.3331 & 1.108 & 6101 \\
\hline 08YL-450-63/4 & pyrite & 0.294 & $6.60 \pm 0.45$ & $2.57 \pm 0.18$ & $1.629 \pm 0.032$ & $0.200 \pm 0.012$ & $392.0 \pm 21.2$ & 24.95 & 24.62 & 0.0959 & 1.504 & 5255 \\
\hline 08MZ-640-12/1 & pyrite & 0.293 & $17.5 \pm 1.2$ & $8.11 \pm 0.60$ & $0.737 \pm 0.013$ & $0.196 \pm 0.016$ & $401.8 \pm 12.9$ & 11.20 & 26.46 & 0.1226 & 1.804 & 10052 \\
\hline 08MZ-640-59 & pyrite & 0.293 & $31.6 \pm 2.1$ & $8.53 \pm 0.57$ & $0.6290 \pm 0.0098$ & $0.190 \pm 0.012$ & $447.7 \pm 30.7$ & 9.54 & 34.00 & 0.0918 & 2.781 & 31396 \\
\hline 08MZ-760-57 & pyrite & 0.412 & $18.9 \pm 1.3$ & $2.93 \pm 0.20$ & $1.229 \pm 0.016$ & $0.182 \pm 0.021$ & $803.1 \pm 41.4$ & 18.78 & 63.21 & 0.0980 & 3.250 & 60241 \\
\hline 08MZ-640-12/2 & arsenopyrite & 0.292 & $1.56 \pm 0.11$ & $0.84 \pm 0.057$ & $3.477 \pm 0.069$ & $0.1842 \pm 0.0098$ & $908.4 \pm 71.5$ & 53.42 & 67.47 & 0.3633 & 0.759 & 723766 \\
\hline
\end{tabular}

a) The error is $1 \sigma ;{ }^{40} \mathrm{Ar}{ }^{*}=\left({ }^{40} \mathrm{Ar}\right)_{\text {sample }} \times\left[1-\frac{\left({ }^{40} \mathrm{Ar} /{ }^{36} \mathrm{Ar}\right)_{\text {atmosphere }}}{\left({ }^{40} \mathrm{Ar} /{ }^{36} \mathrm{Ar}\right)_{\text {sample }}}\right] ; \mathrm{F}^{4} \mathrm{He}=\left({ }^{4} \mathrm{He} /{ }^{36} \mathrm{Ar}\right)_{\text {sample }} /\left({ }^{4} \mathrm{He} /{ }^{36} \mathrm{Ar}\right)_{\text {atmosphere }}$. 
over a depth of $400 \mathrm{~m}$, so cosmogenic He as a source of high ${ }^{3} \mathrm{He} /{ }^{4} \mathrm{He}$ can be ruled out. The nuclear reaction ${ }^{6} \mathrm{Li}(\mathrm{n}, \alpha)^{3} \mathrm{H}(\beta)^{3} \mathrm{H}$ can also produce ${ }^{3} \mathrm{He}$. The supply of $\alpha$-particles for these reactions comes from the decay of Th, $\mathrm{U}$, and daughter isotopes, a process that dominates ${ }^{4} \mathrm{He}$ production. So, the variation of ${ }^{3} \mathrm{He} /{ }^{4} \mathrm{He}$ ratios in minerals or rocks is dependent on the content of $\mathrm{Li}$, Th and $\mathrm{U}$ [44]. According to the calculation of Tolstikhin et al. [45], the accumulative nucleogenic or radiogenic ${ }^{3} \mathrm{He} /{ }^{4} \mathrm{He}$ isotopic ratios of lithium-bearing chlorite ( $\mathrm{Li}$ content is $160 \mathrm{ppm}$ ) and biotite (Li content is $320 \mathrm{ppm}$ ) in Paleozoic gneiss dated at $320 \mathrm{Ma}$ are $0.09 \mathrm{Ra}$ and $0.13 \mathrm{Ra}$, approximately the same as the accepted upper level for the crust, 0.1 Ra [46], and far lower than the expected mantle value (6-9 Ra) [47-50]. However, the samples in this study do not have lithium abundance data. Nevertheless, pyrites and the like are not lithium-bearing, so the $\mathrm{Li}$ content of inclusions in these minerals is far lower than lithium-bearing minerals, and the metallogenic ages are the relatively young Yanshanian $[37,38]$. Therefore, nucleogenic ${ }^{3} \mathrm{He}$ also can be ignored.

Pyrite and the like are known to be suitable He traps with low helium diffusivity $[7,18,51]$, e.g. the original He is retained in sulfides at the late Paleozoic Sawuer gold deposit in Xinjiang, China and Panasqueira W-Cu-Sn deposit in Portugal, with almost no loss of He after mineral formation $[18,19]$. ${ }^{4} \mathrm{He}$ produced by the decay reaction of $\mathrm{U}$ and $\mathrm{Th}$ trapped in mineral lattice or fluid inclusions could decrease ${ }^{3} \mathrm{He} /{ }^{4} \mathrm{He}$ after mineral formation. Studies have shown and documented this in the Panasqueira [18] and Dae Hwa W-Mo deposits in South Korea [3]. Thorium is not dissolved in water; the content in inclusion fluid can be ignored. The present study shows how the melting method was used to release noble gases for isotope content and ratio measurements. He trapped in lattice, solid inclusions or fluid inclusions is released at the same time. Given that the $\mathrm{Th} / \mathrm{U}$ ratio in samples is the crustal average $(\mathrm{Th} / \mathrm{U}=3.6)$ [50], then the metallogenic age is $149 \mathrm{Ma}$, according to the in situ radiogenic ${ }^{4} \mathrm{He}$ production ratio $\left({ }^{4} \mathrm{He}\right.$ atoms $/ \mathrm{g} \mathrm{a}=(3.115 \times$ $\left.\left.10^{6}+1.272 \times 10^{5}\right) \quad[\mathrm{U}]+7.71 \times[\mathrm{Th}] \quad[51]\right)$. To decrease the highest ${ }^{3} \mathrm{He} /{ }^{4} \mathrm{He}$ ratio $(4.362 \mathrm{Ra})$ to the three lowest values $(0.00433,0.0304$ and $0.363 \mathrm{Ra})$, the amounts of $\mathrm{U}$ and $\mathrm{Th}$ needed to produce radiogenic ${ }^{4} \mathrm{He}$ are $11.16,3.1$, and 0.29 ppm, and 1.03, 0.024, and $0.09 \mathrm{ppm}$, respectively. Previous work has shown that the Li contents of sulfides and tungsten-bearing minerals are close to the above values [3,21,30, 53,54]. It therefore seems likely that the analyses in Table 2 have been affected by the contribution of in situ produced radiogenic ${ }^{4} \mathrm{He}$ after trapping, and represent the minimum ${ }^{3} \mathrm{He} /{ }^{4} \mathrm{He}$ ratios from the time of mineral formation. The ${ }^{3} \mathrm{He} /{ }^{4} \mathrm{He}$ ratios of the samples negatively correlate with the ${ }^{4} \mathrm{H}$ contents (Figure 2 ), but the range of ${ }^{3} \mathrm{He}$ contents is narrow. This also suggests that in situ radiogenic ${ }^{4} \mathrm{He}$ is one of the main factors leading to a decrease in the ${ }^{3} \mathrm{He} /{ }^{4} \mathrm{He}$ ratios in the samples.

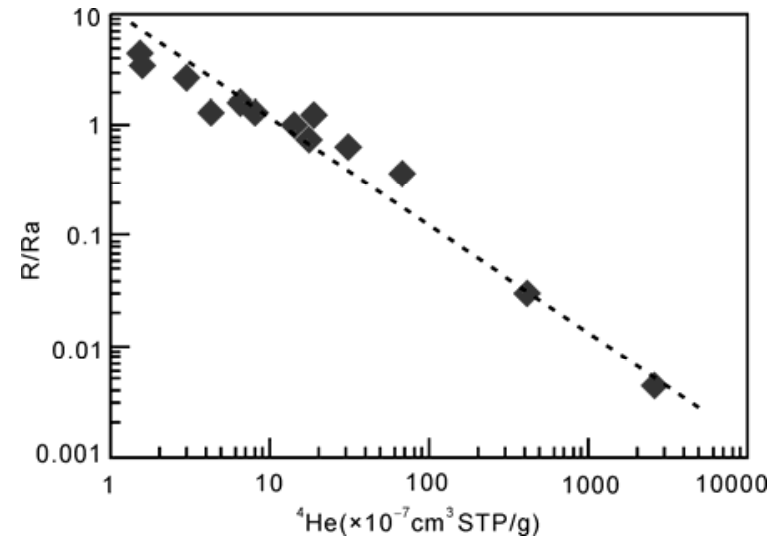

Figure $2{ }^{4} \mathrm{He}$ versus R/Ra.

Compared to the large amount of Ar that is trapped in fluid inclusions, in situ production and diffusion of ${ }^{40} \mathrm{Ar}$ in pyrite is trivial and can be ignored [18,55,56]. Therefore, the variation of ${ }^{40} \mathrm{Ar} /{ }^{36} \mathrm{Ar}$ ratios in Table 2 is more likely due to changes in the proportion of atmospheric Ar that contaminates Ar derived from the fluids.

\subsection{Constraints on the origin of ore-forming fluids from He-Ar isotopes}

Noble gases in hydrothermal fluids originate from three sources.

(1) Air or air-saturated water (ASW). Examples include meteoric water, marine water and formation water. Noble gases in ASW are in equilibrium with the atmosphere at certain temperatures and pressures. ASW is characterized by atmospheric $\mathrm{He}$ and $\mathrm{Ar}$ isotope compositions (negligible isotope fractionation occurs during dissolution of noble gases), therefore ${ }^{3} \mathrm{He} /{ }^{4} \mathrm{He}=1.399 \times 10^{-6}=1 \mathrm{Ra},{ }^{40} \mathrm{Ar} /{ }^{36} \mathrm{Ar}=$ 295.5. Because noble gas solubility in low temperature aqueous fluid decreases with mass $[1,10]$, the solubility of $\mathrm{He}$ in an aqueous setting is lowest, and the He abundance in air is very low. So, He is almost absent from ASW, e.g. $\mathrm{He} / \mathrm{Ar} \approx 1 \times 10^{-4}$. The blocking temperature of Ar, which is highly abundant in air, is considerably higher than that of He [56,57]. Consequently, shallow groundwaters do not entrain radiogenic Ar, and have atmospheric Ar compositions. However, radiogenic ${ }^{4} \mathrm{He}$, produced by the radioactive decay of $U$ and $T h$ in aquifer rocks, will diffuse into groundwater and hydrothermal fluids. So, most shallow groundwater or geological fluids of meteoric or marine origin have ${ }^{3} \mathrm{He} /{ }^{4} \mathrm{He}$ ratios that are lower than the atmospheric value but have atmospheric ${ }^{40} \mathrm{Ar} /{ }^{36} \mathrm{Ar}$, which shows modified air-saturated water (MASW) characteristics [10,51].

(2) Mantle fluid. ${ }^{3} \mathrm{He} /{ }^{4} \mathrm{He}$ ratios for most rocks and fluids derived from oceanic mantle are from 7 to $9 \mathrm{Ra}$. The subcontinental lithospheric mantle is characterized by ${ }^{3} \mathrm{He} /{ }^{4} \mathrm{He}$ ratios of 6-7 $\mathrm{Ra}$, where mantle-derived $\mathrm{Ar}$ is dominated by radiogenic ${ }^{40} \mathrm{Ar}$, with ${ }^{40} \mathrm{Ar} /{ }^{36} \mathrm{Ar}>40000$ [47-50]. 
(3) Crustal fluid. High concentrations of crustal lithophile elements produce radiogenic $\mathrm{Ar}$ and $\mathrm{He}$, with ${ }^{40} \mathrm{Ar} /{ }^{36} \mathrm{Ar}$ ratios $\geqslant 45000$ [58] and ${ }^{3} \mathrm{He} /{ }^{4} \mathrm{He}$ ratios $\leqslant 0.1 \mathrm{Ra}$ [46]. Accordingly, crustal metamorphic or magmatic fluids have He and Ar isotope compositions similar to crustal rocks.

1) High ${ }^{3} \mathrm{He}$ concentrations and ${ }^{3} \mathrm{He} /{ }^{4} \mathrm{He}$ ratios. The concentration of ${ }^{3} \mathrm{He}$ in samples of the Yaoling-Meiziwo tungsten deposit is extremely high, from $0.759 \times 10^{-12} \mathrm{~cm}^{3}$ $\mathrm{STP} / \mathrm{g}$ to $3.463 \times 10^{-12} \mathrm{~cm}^{3} \mathrm{STP} / \mathrm{g}$ (Table 2), which is similar to the high ${ }^{3} \mathrm{He}$ concentration in the Panasqueira W-Cu-Sn deposit in Portugal, higher than in all basaltic phenocrysts, and higher than the majority of mantle xenoliths entrained in basalts [18]. The only plausible source of high ${ }^{3} \mathrm{He}$ concentrations in $\mathrm{He}$ is from the mantle. The ${ }^{3} \mathrm{He} /{ }^{4} \mathrm{He}$ ratio for inclusion fluids in samples range from 0.0043 to $4.362 \mathrm{Ra}$, the extremes of which indicate two end-members in mantle and crustal fluid mixing (Figure 3 ). The high ${ }^{3} \mathrm{He} /{ }^{4} \mathrm{He}$ ratios for inclusion fluids, with the maximum $4.362 \mathrm{Ra}$, are from the mantle; in addition to crustal magmatic fluid related to metallogenesis, the crustal end-member has MASW characteristics. There are obvious linear correlations in the plots of ${ }^{3} \mathrm{He} /{ }^{36} \mathrm{Ar}$ versus ${ }^{40} \mathrm{Ar} /{ }^{36} \mathrm{Ar}$ and ${ }^{40} \mathrm{Ar} * /{ }^{4} \mathrm{He}$ versus $\mathrm{R} / \mathrm{Ra}$ (Figures 4 and 5), which are suggestive of the mixing of high ${ }^{3} \mathrm{He}$ and ${ }^{40} \mathrm{Ar}$ mantle fluid with MASW having low ${ }^{3} \mathrm{He} /{ }^{36} \mathrm{Ar}$ and atmospheric Ar. Because of the insolubility of $\mathrm{He}$ in water and low He concentration of the atmosphere, the ${ }^{3} \mathrm{He} /{ }^{36} \mathrm{Ar}$ ratio of MASW is lower than $1 \times 10^{-7}$ [18]. Consequently, the contribution of atmospheric $\mathrm{He}$ can be ignored. The $\mathrm{He}$ in ore-forming fluids is derived mainly from the crust and mantle. The $\mathrm{F}^{4} \mathrm{He}\left[\mathrm{F}^{4} \mathrm{He}=\left({ }^{4} \mathrm{He} /{ }^{36} \mathrm{Ar}\right)_{\text {sample }} /\right.$ $\left.\left({ }^{4} \mathrm{He} /{ }^{36} \mathrm{Ar}\right)_{\text {air }}\right]$ value for inclusion fluids in samples from Yaoling-Meiziwo range from 686 to $2.7 \times 10^{6}$. This indicates that the He content in the samples is at least 686 times higher than in air. Therefore, atmospheric He in ore-forming fluid can be ignored.

The source of He with a high ${ }^{3} \mathrm{He} /{ }^{4} \mathrm{He}$ ratio in ore-forming fluid for Yaoling-Meiziwo was the local mantle (either lithospheric or asthenospheric) below, e.g. the subcontinental lithospheric mantle ${ }^{3} \mathrm{He} /{ }^{4} \mathrm{He}$ ratio is 6-7 $\mathrm{Ra}[49,50]$. Based on a binary crust-mantle system, the proportion of mantle He can be calculated by formula [51]:

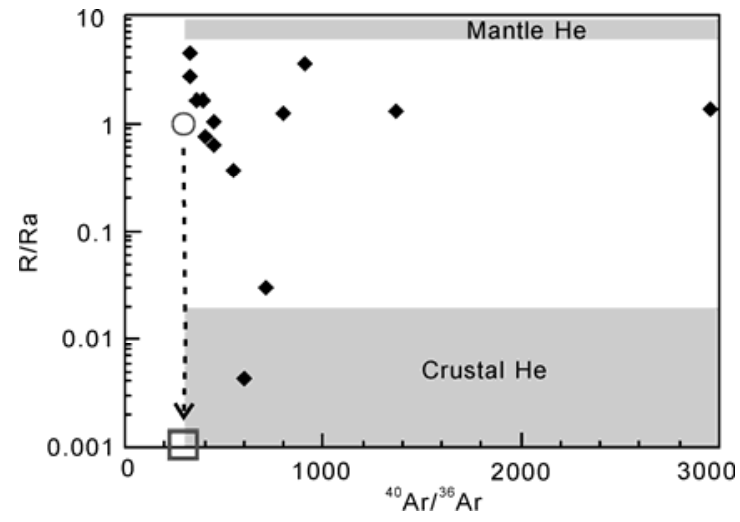

Figure $3{ }^{40} \mathrm{Ar}{ }^{\beta 6} \mathrm{Ar}$ versus R/Ra. $\mathrm{O}$, Atmospheric value; $\square$, MASW [3].

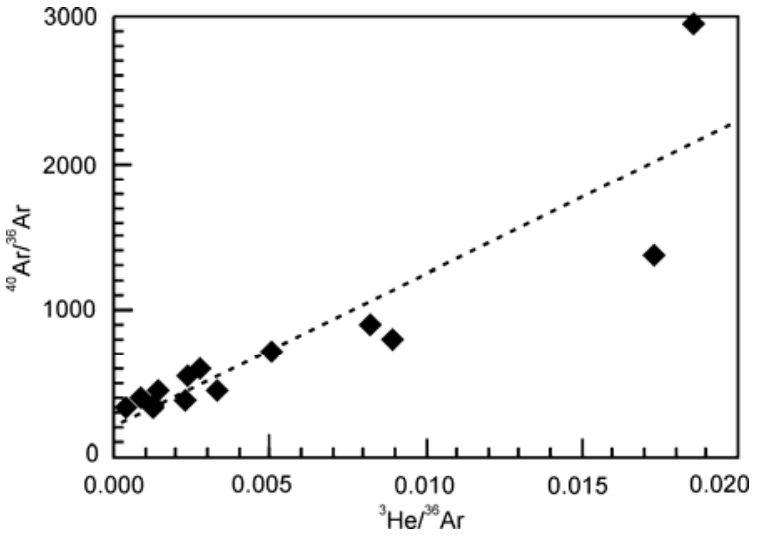

Figure $4{ }^{3} \mathrm{He} /{ }^{36} \mathrm{Ar}$ versus ${ }^{40} \mathrm{Ar} /{ }^{36} \mathrm{Ar}$.

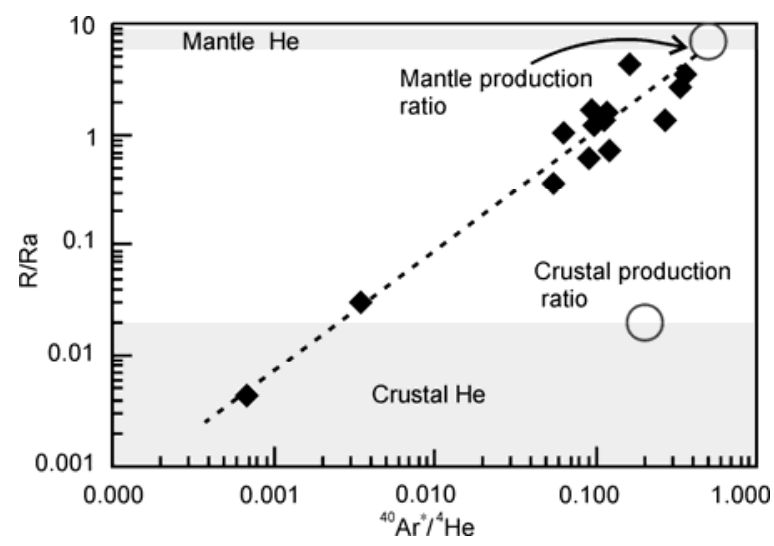

Figure $5 \quad{ }^{40} \mathrm{Ar}^{*} /{ }^{4} \mathrm{He}$ versus $\mathrm{R} / \mathrm{Ra}$.

$$
\mathrm{He}_{\text {mantle }}(\%)=\frac{\left({ }^{3} \mathrm{He} /{ }^{4} \mathrm{He}\right)_{\text {sample }}-\left({ }^{3} \mathrm{He} /{ }^{4} \mathrm{He}\right)_{\text {crust }}}{\left({ }^{3} \mathrm{He} /{ }^{4} \mathrm{He}\right)_{\text {mantle }}-\left({ }^{3} \mathrm{He} /{ }^{4} \mathrm{He}\right)_{\text {crust }}} \times 100 .
$$

Given that the average $\left({ }^{3} \mathrm{He} /{ }^{4} \mathrm{He}\right)_{\text {mantle }}$ ratio for the subcontinental lithospheric mantle is $6.5 \mathrm{Ra}$, and the average $\left({ }^{3} \mathrm{He} /{ }^{4} \mathrm{He}\right)_{\text {crust }}$ ratio for crustal production is $0.02 \mathrm{Ra}$ [3], the calculated average proportion of mantle $\mathrm{He}$ is $22 \%$, and the maximum is $67 \%$. With the exception of one sample, the ${ }^{3} \mathrm{He} /{ }^{4} \mathrm{He}$ is lower than the average crustal production ratio; the calculated results are less, because of the effect of in situ radiogenic ${ }^{4} \mathrm{He}$. The measured ${ }^{3} \mathrm{He} /{ }^{4} \mathrm{He}$ ratios are the possible minima of the samples, and the proportion of mantle $\mathrm{He}$ for inclusion fluid was higher while the deposit was forming.

2) $\mathrm{Ar}$ isotopes and $\mathrm{He}, \mathrm{Ar}$ fractionation. ${ }^{40} \mathrm{Ar} /{ }^{\beta 6} \mathrm{Ar}$ ratios for the inclusion fluids of Yaoling-Meiziwo vary from 330 to 2952 , i.e. between the isotopic ratios of atmospheric and crustal or mantle radiogenic Ar. The proportion of radiogenic ${ }^{40} \mathrm{Ar}^{*}$ can be estimated using the measured ${ }^{40} \mathrm{Ar} /{ }^{36} \mathrm{Ar}$ value as follows [51]:

$$
{ }^{40} \operatorname{Ar}^{*}(\%)=\frac{\left({ }^{40} \mathrm{Ar} /{ }^{36} \mathrm{Ar}\right)_{\text {sample }}-295.5}{\left({ }^{40} \mathrm{Ar} /{ }^{36} \mathrm{Ar}\right)_{\text {sample }}} \times 100 .
$$

The calculated results show that the proportions of radi- 
ogenic ${ }^{40} \mathrm{Ar}^{*}$ are $10.5 \%-90 \%$, with an average of $44.9 \%$. The corresponding atmospheric $\mathrm{Ar}$ is $10 \%-89.5 \%$.

${ }^{40} \mathrm{Ar}^{*} /{ }^{4} \mathrm{He}$ ratios for the inclusion fluids of YaolingMeiziwo vary from 0.0007 to $0.363 .{ }^{3} \mathrm{He} /{ }^{4} \mathrm{He}$ ratios vary from 0.0043 to $4.362 \mathrm{Ra}$. Lithospheric mantle ${ }^{40} \mathrm{Ar}^{*} /{ }^{4} \mathrm{He}=$ 0.5 and ${ }^{3} \mathrm{He} /{ }^{4} \mathrm{He}=6-9 \mathrm{Ra}$, whereas crustal rocks ${ }^{40} \mathrm{Ar}^{*} /{ }^{4} \mathrm{He}=$ 0.2 and ${ }^{3} \mathrm{He} /{ }^{4} \mathrm{He}<0.02 \mathrm{Ra}[3]$. As shown by ${ }^{40} \mathrm{Ar}^{*} /{ }^{4} \mathrm{He}$ versus ${ }^{3} \mathrm{He} /{ }^{4} \mathrm{He}$ (Figure 5), the Yaoling-Meiziwo samples fall in the range between mantle and crust, and there are negative linear correlations with ${ }^{3} \mathrm{He} /{ }^{4} \mathrm{He}$. This suggests that mantle fluid with high ${ }^{40} \mathrm{Ar}^{*} /{ }^{4} \mathrm{He}$ and ${ }^{3} \mathrm{He} /{ }^{4} \mathrm{He}$ ratios mixes with crustal fluid with low ${ }^{40} \mathrm{Ar}{ }^{*} /{ }^{4} \mathrm{He}$ and ${ }^{3} \mathrm{He} /{ }^{4} \mathrm{He}$ ratios. The mantle end-member has the features of the lithospheric mantle, whereas ${ }^{40} \mathrm{Ar}^{*} / 4 \mathrm{He}$ of the crustal end-member is 0.0007 , far below the crustal production ratio of 0.2 . This indicates that, in addition to granite magmatic fluid derived from crust, MASW was involved in the ore-forming fluid. Since minerals in crustal rocks have higher closure temperatures for Ar than $\mathrm{He}$, He will be lost preferentially at lower temperatures by diffusion, groundwaters will preferentially acquire radiogenic He from crustal rocks. Ar is hosted predominantly in potassium feldspar and mica. It is retained by feldspar below $200^{\circ} \mathrm{C}$, by biotite below about $300^{\circ} \mathrm{C}$, and by muscovite below $350^{\circ} \mathrm{C}$ [56]. Below the closure temperatures, Ar will be closed in potassium-bearing minerals, but $\mathrm{He}$ remains active. The He abundance in air is far lower than Ar, and is also lower in air saturated water. Therefore, circulating meteoric waters will preferentially acquire $\mathrm{He}$ from aquifer rocks [3], resulting in "crustal" He compositions, whereas the Ar-signature maintains an atmospheric character. According to hydrogen and oxygen isotope data from the Yaoling-Meiziwo tungsten deposit, the $\delta \mathrm{D}$ values of water in fluid inclusions and muscovite are $-47.8 \%$ $-66.7 \%$, and the $\delta^{18} \mathrm{O}$ values of quartz and muscovite are $2.42 \%$ - 4.24\%o (unpublished data, Zhai et al.). This indicates the involvement of meteoric water in magmatic fluids, and consequently the ore-forming fluid for YaolingMeiziwo is a mixture of mantle fluid, crustal magmatic fluid and MASW.

\subsection{Yanshanian crust-mantle interaction and $W$ and Sn mineralization in southeastern China}

Southeastern China hosts significant tungsten and tin deposits including a series of large and supergiant deposits. Characteristic examples include the Xihuashan, Dajishan and Piaotang tungsten deposits in Jiangxi Province, the Jubankeng and Yaoling-Meiziwo tungsten deposits in Guangdong Province, and the Furong, Qitianling and Shizhuyuan tin or tungsten-tin deposits in Hunan Province. Since the 1980s, much research has considered how these deposit are related to crustal anatectic or S-type granites, which have a higher initial ${ }^{87} \mathrm{Sr} /{ }^{86} \mathrm{Sr}$ ratio, higher $\delta^{18} \mathrm{O}$, and lower $\varepsilon_{\mathrm{Nd}}(t)$ values, and also, the protoliths of these granites are regional basement rocks [31-36], indicating that large-scale ore-forming fluid related to the tungsten and tin mineralization was derived from the crust.

$\mathrm{He}$ and $\mathrm{Ar}$ isotope analysis from the Yaoling-Meiziwo deposit shows that ore-forming fluids have higher ${ }^{3} \mathrm{He}$ contents (from $0.759 \times 10^{-12} \mathrm{~cm}^{3} \mathrm{STP} / \mathrm{g}$ to $3.463 \times 10^{-12} \mathrm{~cm}^{3} \mathrm{STP} / \mathrm{g}$ ) and a wide range of ${ }^{3} \mathrm{He} /{ }^{4} \mathrm{He}$ ratios (maximum of $4.362 \mathrm{Ra}$ ), indicating the involvement of mantle fluid in the mineralization. The average proportion of mantle $\mathrm{He}$ is $22 \%$ and the maximum is $67 \%$, which means that mantle fluid plays an important role in tungsten mineralization. In the central part of Nanling mountain, in southeastern China, the ${ }^{3} \mathrm{He} /{ }^{4} \mathrm{He}$ ratios of ore-forming fluids for the granite-related Qitanling, Tianmenzhang, Xitan, Danchidai and Xianghualing tin deposits are in the rang of $0.75-5.32 \mathrm{Ra}$. This indicates mantle fluid association in mineralization, and in the Guposhan granite-related tin deposit, with ${ }^{3} \mathrm{He} /{ }^{4} \mathrm{He}$ ratios of oreforming fluid ranging from 14.74 to $28.58 \mathrm{Ra}$, further indicating mantle plume fluid involvement in the mineralization [22]. In the Piaotang granite-related tungsten deposit in Jiangxi Province, ${ }^{3} \mathrm{He} /{ }^{4} \mathrm{He}$ ratios of ore-forming fluid are 0.17-0.86 Ra [28], indicating that they also had mantle volatile involvement. In South Korea, ore-forming fluid ${ }^{3} \mathrm{He} /{ }^{4} \mathrm{He}$ ratios for Dae Hwa W-Mo deposit are 0.71-1.43 $\mathrm{Ra}$ [3]; in the Panasqueira W-Cu-Sn deposit in Portugal, ${ }^{3} \mathrm{He} /{ }^{4} \mathrm{He}$ ratios are 4.6-5.4 $\mathrm{Ra}$ for inclusion fluids in arsenopyrite, and 1.8 Ra for those in wolframite [18], all proving the involvement of mantle fluid in mineralization. $\delta^{13} \mathrm{C}$ values of gangue mineral shiver spar in the famous Chinese Xihuashan are $-4.51 \%$ o to $-7.53 \%$ o, averaging $-6.47 \%$ o (6 samples), also indicating the involvement of mantle $\mathrm{CO}_{2}$ in mineralization [59].

Noble gases in the mantle are trapped in minerals and, without magma generation and transport, could not reach the Earth's surface because diffusion, even at mantle temperatures, does not enable significant transport distances over geological time. It is likely that the occurrence of mantle derived noble gases and volatiles in crustal fluids indicate the partial melting of mantle rocks, magma intrusion and degassing at depth [51,60]. Stuart et al. [3] suggested that high ${ }^{3} \mathrm{He} /{ }^{4} \mathrm{He}$ ratios in ore-forming fluids related to granite emplacement for the Dae Hwa W-Mo deposit in South Korea provides strong evidence that crustal melting was triggered by mantle melting during subduction of the Pacific Plate in the Cretaceous. Burnard and Polya [18] suggested that high ${ }^{3} \mathrm{He} /{ }^{4} \mathrm{He}$ ratios $(4.6-5.4 \mathrm{Ra})$ in the ore-forming fluid for the Panasqueira W-Cu-Sn deposit in Portugal are due to the result of hydrothermal activity derived from mantle magma crystallization after the cooling of granite. The granitic magmatic hydrothermal system derived from crustal melting does not have such high ${ }^{3} \mathrm{He} /{ }^{4} \mathrm{He}$ ratios.

The Yaoling-Meiziwo deposit is located in the southern part of the southeastern China tungsten and tin metallogenic belt. The ore-forming fluids there have high ${ }^{3} \mathrm{He}$ contents and high ${ }^{3} \mathrm{He} /{ }^{4} \mathrm{He}$ ratios. In the northwestern (Qitianling, 
Xitian, Xianghualing and Guposhan tin deposits) and northern (Piaotang and Xihuashan tungsten deposits) parts of the metallogenic belt, the ore-forming fluids all have the involvement of mantle volatiles and high ${ }^{3} \mathrm{He} /{ }^{4} \mathrm{He}$ ratios $[22,28,59]$, and the ages of the granites related to the metallogenesis and mineralization are all clustered in the range of 150-160 Ma in middle Yanshanian period. These deposits show a temporal and spatial metallogenic explosion [37,38,61-64]. The ore-forming fluids have both high ${ }^{3} \mathrm{He} /{ }^{4} \mathrm{He}$ ratios and the involvement of mantle volatiles for Yaoling-Meiziwo and other tungsten and tin deposits in southeastern China. This suggests that mantle melting and magmatic intrusion occurred at the same time as the large-scale tungsten and tin mineralization related to granite in the middle Yanshanian period. Examples include alkaline basalt, syenite, diorite, gabbro and A-type granite that formed in the middle Yanshanian period in southern Hunan and Jiangxi, and north Guangdong province [65-69]. Previous lithogeochemical and tectonic research results proposed two models to explain the interaction between the granitic genesis related to tungsten and tin metallogenesis and mantle magma. Zhou and $\mathrm{Li}$ [70] suggested that during the middle Yanshanian period, the Paleo-Pacific Plate subducted beneath the Eurasian continent at a low angle, leading to dehydration and partial melting of the subducted slab, metasomatism and partial melting of the mantle wedge, and generation of basaltic magmas. These basaltic magmas were underplated beneath the lower crust, leading to the generation of crustal granitic magma, magmatic fractionation, and the eventual release of magmatic fluids that formed the world-class $\mathrm{W}$ and $\mathrm{Sn}$ deposits of southeastern China. Li and $\mathrm{Li}$ [71] proposed a flat-slab subduction model to explain the tectonic evolution of southern China that started at the end of the Permain and proceeded during the Mesozoic. Because of the flat-slab subduction of the Paleo-Pacific Plate, the Indosinian orogen propagated to the northwest of the South China block, until ca. 190 Ma. Orogenesis then ended and evolved into an anorogenic stage until ca. 150 Ma. The subducted slab then detached and foundered, and the asthenospheric mantle uplifted and partially melted to generate basaltic magma underplating or intrusion into the crust. Finally, this led to crustal rocks melting to generate granites.

The characteristics of the temporal and spatial distributions of the $\mathrm{W}$ and $\mathrm{Sn}$ deposits are related to granite in southeastern China. These deposits are distributed in southern Jiangxi, Hunan, northern Guangdong, and Guangxi provinces, in the region where the four provinces come together. The ages of the granite and associated deposits are mainly in the range of 150-160 Ma, and they show clustered and explosive mineralization features [61-64]. If the flat-slab subduction model is correct, it can be used to explain $\mathrm{W}$ and $\mathrm{Sn}$ metallogenesis in the middle Yanshanian period in southeastern China more rationally. According to the flat-slab subduction model [71], the subducted slab broke off and foundered starting ca. $190 \mathrm{Ma}$ and ending ca. $150 \mathrm{Ma}$. The large-scale foundering occurred from 180 to $155 \mathrm{Ma}$. The asthenosphere uplifted and extended the crust of southeastern China. The uplifted asthenosphere developed partial melts that generated basaltic magma underplating or intrusion into the crust. The crustal rocks melted to generate large-scale S-type granitic magma during the middle Yanshanian period in southeastern China, because of the injection of mantle magmas and heat. The magma crystallization led to the release of tungsten- and tin-bearing magmatic fluids mixed with high ${ }^{3} \mathrm{He} /{ }^{4} \mathrm{He}$ mantle fluids released from mantle magma crystallization and MASW circulating in crustal rocks. These fluids were injected into extensional faults or cracks to form the world-class W and Sn deposits of southeastern China.

The involvement of mantle fluid in mineralization does not mean that the ore metal is derived from the mantle. Instead, W and Sn may be derived mainly from crustal granitic magma. The involvement of mantle fluid in the mineralization suggests that the $\mathrm{W}$ and $\mathrm{Sn}$ deposits in southeastern China are the result of the tectonic evolution of crust-mantle interactions. A-type granites, syenites, diorites and basic intrusive rocks formed at the same time with large-scale S-type granites in southeastern China in the middle Yanshanian period thereby providing robust evidence for this tectonic process [65-69].

\section{Conclusions}

(1) Measurements of $\mathrm{He}$ and Ar isotope abundances and ratios for inclusion fluids at the Yaoling-Meiziwo deposit suggest that mantle He has been involved in the ore-forming fluid. The average proportion of mantle $\mathrm{He}$ is $22 \%$; the maximum is $67 \%$. So, mantle fluid apparently played a vital role in the metallogenesis.

(2) He and Ar isotopic fractionation suggests that in addition to the involvement of the mantle fluid, MASW with a high ${ }^{4} \mathrm{He}$ content has been involved in the ore-forming fluid. The involvement of mantle fluids does not mean that the $\mathrm{W}$ and $\mathrm{Sn}$ are derived from the mantle. In fact, the ore-forming fluid is a mixture of mantle fluids, crustal magmatic fluids and MASW.

(3) The involvement of mantle fluids indicates that large-scale $\mathrm{W}$ and $\mathrm{Sn}$ metallogenesis, including that which occurred at Yaoling-Meiziwo, is the result of crust-mantle interaction in the middle Yanshanian period. The PaleoPacific Plate underwent flat-slab subduction and foundered. The crust in southeastern China developed an extensional tectonic background. The uplift of asthenoshperic partial melt generated basaltic magma underplating or intrusion into the crust, which led to the generation of large-scale S-type granitic magmas. The crustal magmatic fluid mixed with mantle fluid with a high ${ }^{3} \mathrm{He} /{ }^{4} \mathrm{He}$ ratio and MASW convection in the crustal rocks, and injected any extensional 
tectonic faults or cracks to form the world-class $\mathrm{W}$ and $\mathrm{Sn}$ deposits of southeastern China.

The geological technical staff in the Yaoling-Meiziwo Tungsten Mine are thanked for their support during fieldwork. We are grateful to Drs. Li Wenqian and Li Shehong of the Guangzhou Institute of Geochemistry, CAS, for their help in field sampling. We also thank the two reviewers for constructive review comments that helped us improve the manuscript. This work was supported by the National Basic Research Program of China (2007CB411404), the National Natural Science Foundation of China (40873034) and the Guangdong Province Universities and Colleges Pearl River Scholar Funded Scheme (2011).

1 Simmons S F, Sawkins F J, Schulutter D J. Mantle-derived helium in two Peruvian hydrothermal ore deposits. Nature, 1987, 329: 429-432

2 Turner G, Stuart F M. Helium/heat ratios and deposition temperatures of sulphides from the ocean floor. Nature, 1992, 357: 581-583

3 Stuart F M, Burnard P, Taylor R P, et al. Resolving mantle and crustal contributions to ancient hydrothermal fluid: He-Ar isotopes in fluid inclusions from Dae Hwa W-Mo mineralization, South Korea. Geochim Cosmochim Acta, 1995, 59: 4663-4673

4 Pettke T, Frei R, Kramers J D, et al. Isotope systematics in vein gold from Brusson, Val d'Ayas (NW Italy) 2. (U+Th)/He and K/Ar in native Au and its fluid inclusions. Chem Geol, 1997, 135: 173-187

$5 \mathrm{Hu}$ R Z, Bi X W, Truner G, et al. He-Ar isotopic systematics of fluid inclusions in pyrite from Machangqing copper deposit, Yunnan, China (in Chinese). Sci China Ser D-Earth Sci, 1997, 27: 503-508

$6 \mathrm{Hu} \mathrm{R} \mathrm{Z,} \mathrm{Zhong} \mathrm{H,} \mathrm{Ye} \mathrm{Z} \mathrm{J,} \mathrm{et} \mathrm{al.} \mathrm{Helium} \mathrm{and} \mathrm{argon} \mathrm{isotopic} \mathrm{geochem-}$ istry of Jinding superlarge $\mathrm{Pb}-\mathrm{Zn}$ deposit (in Chinese). Sci China Ser D-Earth Sci, 1998, 28: 208-213

7 Hu R, Burnard P G, Turner G, et al. Helium and Argon isotope systematics in fluid inclusions of Machangqing copper deposit in west Yunnan Province, China. Chem Geol, 1998, 146: 55-63

8 Hou Z Q, Li Y H, Ai Y D, et al. He isotopic composition of the active hydrothermal system in Okinawa trough: Evidence for magmatic helium (in Chinese). Sci Chin Ser D-Earth Sci, 1999, 29: 155-162

9 Hu R Z, Bi X W, Truner G, et al. He and Ar isotope geochemistry of ore-forming fluid in Ailaoshan gold metallogenic belt (in Chinese). Sci China Ser D-Earth Sci, 1999, 29: 321-330

10 Burnard P G, Hu R, Turner G, et al. Mantle, crustal and atmospheric noble gases in Ailaoshan gold deposits, Yunnan Province, China. Geochim Cosmochim Acta, 1999, 63: 1595-1604

11 Sun X M, Norman D I, Sun K, et al. $\mathrm{N}_{2}-\mathrm{Ar}-\mathrm{He}$ systematics and source of ore-forming fluid in Changkeng Au-Ag deposit, Central Guangdong, China (in Chinese). Sci China Ser D-Earth Sci, 1999, 42: 474-481

12 Kendrick M A, Burgess R, Pattrick R A D, et al. Fluid inclusion noble gas and halogen evidence on the origin of $\mathrm{Cu}$-porphyry mineralizing fluids. Geochim Cosmochim Acta, 2001, 65: 2651-2668

13 Kendrick M A, Burgess R, Leach D, et al. Hydrothermal fluid origins in Mississippi valley-type ore districts: Combined noble gas (He, $\mathrm{Ar}$, $\mathrm{Kr}$ ) and halogen $(\mathrm{Cl}, \mathrm{Br}, \mathrm{I})$ analysis of fluid inclusions from the Illinois-Kentucky fluorspar district, Viburnum Trend and Tri-State districts, Midcontinent United States. Econ Geol, 2002, 97: 453-469

14 Kendrick M A, Burgess R, Pattrick R A D, et al. Hydrothermal fluid origins in a fluorite-rich Mississippi valley-type district: Combined noble gas ( $\mathrm{He}, \mathrm{Ar}, \mathrm{Kr})$ and halogen $(\mathrm{Cl}, \mathrm{Br}, \mathrm{I})$ analysis of fluid inclusions from the South Pennine ore field, United Kingdom. Econ Geol, 2002, 97: 435-451

15 Zhao K D, Jiang S Y, Xiao H Q, et al. Origin of ore-forming fluids of the Dachang Sn-polymetallic ore deposit: Evidence from helium isotopes. Chin Sci Bull, 2002, 47: 1041-1045

16 Mao J W, Li Y Q, Goldfarb R J, et al. Fluid inclusion and noble gas studies of the Dongping gold deposit, Hebei Province, China: A mantle connection for mineralization? Econ Geol, 2003, 98: 517-534

17 Hu R Z, Burnard P G, Bi X W, et al. Helium and argon isotope geochemistry of alkaline intrusion-associated gold and copper deposits along the Red River-Jinshajiang fault belt, SW China. Chem Geol, 2004, 203: 305-317

18 Burnard P G, Polva D A. Importance of mantle derived fluids during granite associated hydrothermal circulation: $\mathrm{He}$ and $\mathrm{Ar}$ isotopes of ore minerals from Panasqueira. Geochim Cosmochim Acta, 2004, 68: $1607-1615$

19 Shen P, Shen Y C, Zeng Q D, et al. Helium and argon isotope systematics in fluid inclusion of the Sawuer gold metallogenic belt, Xinjiang. Chin Sci Bull, 2004, 49: 1408-1414

20 Sun X M, Wang M, Xue T, et al. He-Ar isotopic systematics of fluid inclusions in pyrites from PGE-polymetallic deposits in Lower Cambrian black rock series, South China. Acta Geol Sin, 2004, 78: 471-475

21 Graupner T, Niedermann S, Kempe U, et al. Origin of ore fluids in the Muruntau gold system: Constraints from noble gas, carbon isotope and halogen data. Geochim Cosmochim Acta, 2006, 70: 5356-5370

22 Liu Y H, Fu J M, Long B L, et al. He and Ar isotopic components of main tin deposits from central Nanling region and its signification (in Chinese). J Jilin Univ (Earth Sci Edition), 2006, 36: 774-786

23 Sun X M, Xiong D X, Wang S W, et al. Noble gases isotopic composition of fluid inclusions in scheelites collected from Daping gold mine, Yunnan province, China, and its metallogenic significance (in Chinese). Acta Petrol Sin, 2006, 22: 725-732

24 Zhai W, Sun X M, He X P, et al. Noble gas isotopic geochemistry of Axi gold deposit, and its metallogenic implications, Xinjiang, China (in Chinese). Acta Petrol Sin, 2006, 22: 2590-2596

25 Li X F, Mao J W, Wang C Z, et al. The Daduhe gold field at the eastern margin of the Tibetan Plateau: He, Ar, S, O, and $\mathrm{H}$ isotopic data and their metallogenic implications. Ore Geol Rev, 2007, 30: 244-256

26 Sun X M, Xue T, He G W, et al. Noble gas isotopic compositions of cobalt-rich ferromanganese crusts from the western Pacific Ocean and their geological implications. Acta Geol Sin, 2007, 81: 90-98

27 Hu R, Burnard P G, Bi X, et al. Mantle-derived gaseous components in ore-forming fluids of the Xiangshan uranium deposit, Jiangxi Province, China: Evidence from $\mathrm{He}$, Ar and $\mathrm{C}$ isotopes. Chem Geol, 2009, 266: 86-95

28 Wang X D, Ni P, Jiang S Y, et al. Origin of ore-forming fluid in the Piaotang tungsten deposit in Jiangxi Province: Evidence from helium and argon isotopes (in Chinese). Chin Sci Bull (Chin Ver), 2009, 54: 3338-3344

29 Zhu L M, Zhang G W, Guo B, et al. He-Ar isotopic system of fluid inclusions in pyrite from the molybdenum deposits in south margin of North China Block and its trace to metallogenetic and geodynamic background. Chin Sci Bull, 2009, 54: 2479-2492

30 Graupner T, Niedermann S, Rhede D, et al. Multiple sources for mineralizing fluids in the Charmitan gold (-tungsten) mineralization (Uzbekistan). Miner Deposits, 2010, 45: 667-682

$31 \mathrm{Xu} \mathrm{K}$, Sun N, Wang D. Granite and metallogenesis in South China. In: $\mathrm{Xu} \mathrm{K}, \mathrm{Tu} \mathrm{G}$, eds. Geology of Granites and Their Metallogenic Relations. Nanjing: Jiangsu Science and Technology Press, 1984. $1-20$

32 Mo Z S. A discussion on the classification of Nanling granites according to geological environment. Geotect Metallog, 1985, 9: 1-8

33 Wang L, Huang Z. Liquid phase separation and experiment for Li-F granite. Beijing: Science Press, 2000. 1-280

34 Wang D, Ren Q. The Mesozoic Volcanic-Intrusive Complexes and Their Metallogenic Relations in East China. Beijing: Science Press, 1996. 159

35 Hua R M, Chen P R, Zhang W L, et al. Metallogenic systems related to Mesozoic and Cenozoic granitoids in South China (in Chinese). Sci China Ser D-Earth Sci, 2003, 46: 816-829

36 Hua R M, Chen P R, Zhang W L, et al. Metallogeneses and their geodynamic settings related to Mesozoic granitoids in the Nanling range (in Chinese). Geol J Chin Univ, 2005, 11: 291-304

37 Zhai W, Sun X M, Wu Y S, et al. ${ }^{40} \mathrm{Ar}^{-39} \mathrm{Ar}$ dating of Yaoling tungsten deposit in northern Guangdong Province and SHRIMP U-Pb zircon age of related granites (in Chinese). Miner Deposit, 2011, 30: 21-32 
38 Zhai W, Sun X M, Wu Y S, et al. SHRIMP U-Pb zircon ages of Buried Granodiorite, Muscovite ${ }^{40} \mathrm{Ar} /{ }^{39} \mathrm{Ar}$ mineralization age and their geological implications of Meiziwo tungsten deposit, north Guangdong province, China (in Chinese). Geol J Chin Univ, 2010, 16: 161-176

39 Li S, Li W, Wang $\mathrm{H}$, et al. The discovery and importance of Monzogranite in Meiziwo tungsten deposit, North Guangdong province. Acta Miner Sin, 2009, 29(Suppl): 57-59

$40 \mathrm{Gu}$ J. The tungsten ore-vein zonation in South China. In: Yu H, ed. Proceedings of Symposium on Tungsten Geology. Beijing: Geological Publishing House, 1984. 35-45

41 Ye X R, Wu M B, Sun M L. Determination of the noble gas isotopic composition in rocks and minerals by mass spectrometry (in Chinese). Rock Mineral Anal, 2001, 20: 174-178

42 Ye X R, Tao M X, Yu C A, et al. Helium and neon isotopic compositions in the ophiolites from the Yarlung Zangbo River, Southwestern China: The information from deep mantle (in Chinese). Sci China Ser D-Earth Sci, 2007, 50: 801-812

43 Kurz M D. In situ production of cosmogenic helium and some applications to geochronology. Geochim Cosmochim Acta, 1986, 50: 2855-2862

44 Mamyrin B A, Tolstihkin I N. Helium Isotopes in Nature. Amsterdam: Elsevier, 1984. 273

45 Tolstikhin I, Lehmann B E, Loosli H H, et al. Helium and argon isotopes in rocks, minerals, and related groundwaters: A case study in northern Switzerland. Geochim Cosmochim Acta, 1996, 60: 14971514

46 Andrews $\mathbf{J}$ N. The isotopic composition of radiogenic helium and its use to study grounderwater movement in confined aquifers. Chem Geol, 1985, 49: 339-351

47 Porcelli D R, O'Nions R K, Galer S G, et al. Isotopic relationships of volatile and lithophile trace elements in continental ultramafic xenoliths. Contrib Mineral Petrol, 1992, 110: 528-538

48 Patterson D B, Honda M, McDougall I. Noble gases in mafic phenocrysts and xenoliths from New Zealand. Geochim Cosmochim Acta, 1994, 58: 4411-4428

49 Dunai T J, Baur H. Helium, neon and argon systematics of the European subcontinental mantle: Implications for its geochemical evolution. Geochim Cosmochim Acta, 1995, 59: 2767-2784

50 Reid M R, Graham D W. Resolving lithospheric and sub-lithospheric contributions to helium isotope variations in basalts. Earth Planet Sci Lett, 1996, 144: 213-222

51 Ballentine C J, Burnard P G. Production, release and transport of noble gases in the continental crust. Rev Mineral Geochem, 2002, 47: 481-538

52 Taylor S R, McLennan S M. The Continental Crust: Its Composition and Evolution. Oxford: Blackwell, 1985. 312

53 Laou C, Brichet E. Ages and implications of East Pacific Rise sulphide deposit at 21N. Nature, 1982, 300: 169-171

54 Laou C, Brichet E. On the isotopic chronology of submarine hydrothermal deposits. Chem Geol, 1987, 65: 197-207

55 York D, Masliwec A, Kuybida $\mathrm{P}$, et al. ${ }^{40} \mathrm{Ar}-{ }^{39} \mathrm{Ar}$ dating of pyrite. Nature, 1982, 300: 52-53
56 McDougall I, Harrison T M. Geochronology and Thermochronology by the ${ }^{40} \mathrm{Ar}-{ }^{39} \mathrm{Ar}$ method. Oxford: Oxford University Press, 1988. 269

57 Elliot T, Ballentine C J, O'Nions R K, et al. Carbon, helium, neon and argon isotopes in a Po basin natural gas field. Chem Geol, 1993, 106: 429-440

58 Fontes, J C, Andrews, J N, Walgenwitz F. Evaluation of natural in situ production of argon-36 via chlorine-36; Geochemical and geochronological implications. Comptes Rendus de l'Academie des Sciences, Serie 2, Mecanique, Physique, Chimie, Sciences de 1'Univers, Sciences de la Terre, 1991, 313: 649-654

$59 \mathrm{Mu} \mathrm{Z}$, Huang F, Chen C, et al. Study on H, O isotope for PiaotangXihuashan quartz-vein type tungsten deposit. In: Yu H, ed. Proceedings of Symposium on Tungsten Geology. Beijing: Geological Publishing House, 1984. 153-169

60 Ballentine C J, Burgess R, Marty B. Tracing fluid origin, transport and interaction in the crust. Rev Mineral Geochem, 2002, 47: 539-614

61 Hua R M, Mao J W. A preliminary discussion on the Mesozoic metallogenic explosion in East China (in Chinese). Miner Deposit, 1999, 18: 300-307

62 Hua R M, Chen P R, Zhang W L, et al. Three major metallogenic events in Mesozoic in South China (in Chinese). Miner Deposit, 2005, 24: 99-107

63 Mao J W, Xie G Q, Guo C L, et al. Spatial-temporal distribution of Mesozoic ore deposits in South China and their metallogenic settings (in Chinese). Geol J Chin Univ, 2008, 14: 510-526

64 Mao J W, Xie G Q, Cheng Y B, et al. Mineral deposit models of Mesozoic ore deposits in South China (in Chinese). Geol Rev, 2009, 55: $347-354$

65 Zhao Z H, Bao Z W, Zhang B Y, et al. Crustal-mantle interaction background for the formation of the Shizhuyuan super-large tungsten poly-metallic deposit (in Chinese). Sci China Ser D-Earth Sci, 2000, 30(Suppl): 161-168

66 Li X H, Chen Z, Liu D Y, et al. Jurassic gabbro-granite-syenite suites from southern Jiangxi province, SE China: Age, origin, and tectonic significance. Inter Geol Rev, 2003, 45: 898-921

67 Li X H, Li Z X, Li W X, et al. U-Pb zircon, geochemical and Sr-Nd-Hf isotopic constraints on age and origin of Jurassic I- and A-type granites from central Guangdong, SE China: A major igneous event in respond to foundering of a subducted flat-slab? Lithos, 2007, 96: 186-204

68 Xu X S, Lu W M, He Z Y. Age and generation of Fogang granite batholith and Wushi diorite-horblende gabbro body (in Chinese). Sci China Ser D-Earth Sci, 2007, 37: 27-38

69 Li X H, Li X W, Wang X C, et al. Role of mantle-derived magma in genesis of early Yanshanian granites in the Nanling Range, South China: In situ zircon Hf-O isotopic constraints (in Chinese). Sci China Ser D-Earth Sci, 2009, 52: 1262-1278

70 Zhou X M, Li W X. Origin of late Mesozoic igneous rocks in Southeastern China: Implications for lithosphere subduction and underplating of mafic magmas. Tectonophysics, 2000, 326: 269-287

71 Li Z X, Li X H. Formation of the 1300-km-wide intra-continental orogen and post-orogenic magmatic province in Mesozoic South China: A flat-slab subduction model. Geology, 2007, 35: 179-182

Open Access This article is distributed under the terms of the Creative Commons Attribution License which permits any use, distribution, and reproduction in any medium, provided the original author(s) and source are credited. 